\title{
Effects of Humic Acid on the Germination Traits of Pumpkin Seeds under Cadmium Stress
}

\author{
Maasoumeh ASADI ${ }^{1}$, Mohammad SEDGHI ${ }^{2}$, RaoufSeyed SHARIFI ${ }^{2}$ \\ ${ }^{1}$ Department of Agronomy and Plant Breeding, University of Mohaghegh Ardabili; College of \\ Agricultural Sciences, Ardabil, Iran; asadi.m66@gmail.com ("corresponding author) \\ ${ }^{2}$ University of Mohaghegh Ardabili; Ardabil; Iran
}

\begin{abstract}
The study tackled the effect of humic acid and cadmium concentrations on the pumpkin seed germination characteristics throughout were studied. Treatments were cadmium concentrations on three levels: 0, 100 and 200 ppm and humic acid concentration of 0, 100, 200, 300 and $400 \mathrm{mg} \mathrm{lit}^{-1}$. Results showed that interaction of humic acid and cadmium was not significant on germination traits, but there was a significant effect on seedling growth indexes. Radicle and plumule length increased by 86 and 192\% in comparison with control, of the mixture of $200 \mathrm{ppm}$ cadmium and $300 \mathrm{mg} \mathrm{lit}^{-1}$ of humic acid. Cadmium had stimulatory effect on radicle and cotyledon dry weight and the highest values obtained with $200 \mathrm{ppm}$ in mixture with $200 \mathrm{mg} \mathrm{lit}^{-1}$ of humic acid. Also, maximum plumule dry weight was recorded in $200 \mathrm{ppm}$ cadmium and $300 \mathrm{mg} \mathrm{lit}^{-1}$ of humic acid. The highest of indexes were observed of $200 \mathrm{ppm}$ cadmium and 400 $\mathrm{mg} \mathrm{lit}{ }^{-1}$ humic acid. In conclusion, the humic acid had detoxifying effect on cadmium stress in the culture and responded antagonistically against cadmium, but it seems that these concentrations of cadmium are low for the pumpkin seed and can be increased in order to reach the toxicity level.
\end{abstract}

Key words: cadmium, germination, humic acid, pumpkin, seedling growth

\section{Introduction}

Soil contamination with heavy metals is a major problem in agricultural lands that affects the fauna and flora of soils, resulting in the reduction of the quality of products. Heavy metals can be accumulated via the erosion of rocks and soil colloids, but the main source is the human activities using chemical fertilizers, industrial sewage, and agrochemicals. Cadmium (cd) is one of the heavy metals which has high mobility in the soil, while its absorbance by plants leads to toxicity and environmental hazards for humans and animals (Mojahedi et al., 2011).

Pumpkin (Cucurbita pepo L.) is a valuable medicinal plant due to its pharmaceutical characteristics and its oil extract is used in pharmacy. Pumpkin grain oil content is about 35-55\% (Tyler et al., 1988). The most important oil composition is linoleic and oleic acids, sterols, micro nutrient elements, vitamins and carotenoids. Fatty acids like palmitic, stearic, oleic and linoleic acids are present in the pumpkin grain oil, which linoleic (44-55\%) and oleic (27-38\%) acids are present in a higher percentage. Sterols free of glycosides contain about $0.1 \%$ of total extractable oil. Micro nutrient elements consist of zinc, selenium and potassium, while zinc and selenium have great importance from the point of view of human nutrition. Vitamins are $0.03 \%$ of the oil, and the major one is y -tocopherol (vita- min E). Essential amino acids and cucurbitin are the other parts of grain constituents (Lashkari and Seokabarghi, 1998). Vitamin $\mathrm{E}$ is an antioxidant and prevents vitamin A degradation.

Mohammadzadeh et al. (2011) reported that lead (Pb) and $\mathrm{Cd}$, had the lowest respectively highest negative effect on the germination traits of annual alfalfa and the sensitivity of roots to heavy metals was greater than that of aerial parts. Al-Rumaih et al. (2001) showed that $\mathrm{CdCl}_{2}$ caused the reduction in germination percentage and rate in cowpea, but increased the mean of germination time. These responses were dose-related and under high concentrations of $\mathrm{CdCl}_{2}$ more reduction was observed in germination traits. There is a linear relation between seed germination and Cd concentration (Cheng and Zhou, 2002). Eghareba and Omoregie (2010) demonstrated that Cd decreased the germination percentage and plant height in Vigna unguiculata. In Pisum sativum, $40 \mathrm{ppm}$ of Cd has a vital effect on $50 \%$ of seeds and can reduce germination, embryo growth, NADPH, H+ concentration, and number of mitochondria and peroxisomes (Smiri, 2010). Cd usually accumulates in root cells and slightly moves to leaves and causes to decrease in dry and fresh weight and leaf area (Soltani et al., 2007). Humus contains humic acid (HA) and folic acid which constitutes about of $70-75 \%$ of soil organic matter (Turkman et al., 2005). Organic mate- 
rials have hormone-like properties and cause the increase in germination percentage, root development and rapid growth of aerial parts of plants (Tan, 2003).

Humic acid (HA) increased lettuce seedlings dry and fresh weight significantly due to cell elongation and efficient water uptake, but tomato seedlings were not different in dry weight in response to HA (Piccolo et al., 1993). Priming of sunflower seeds with HA had no significant effect on radicle and plumule dry weight, while Cd severely affected these traits (Mojahedi et al., 2011). Jafari et al. (2011) reported that biologic fertilizers like HA and biophosphorous increased radicle and plumule length of two wheat cultivars. Since soil contamination with heavy metals is one of the major problems for seed germination, the objective of this study was to determine the HA potential for $\mathrm{Cd}$ detoxifying in pumpkin-cultivation soils.

\section{Materials and methods}

In order to determine the effect of humic acid and cadmium on the germination traits of pumpkin seeds, a factorial experiment was conducted based on completely randomized design with three replications. Treatments involved different concentrations of cadmium solution including 0,100 and $200 \mathrm{ppm}$ and humic acid as 0, 100, 200, 300, and $400 \mathrm{mg} \mathrm{lit}^{-1}$. Pumpkin seeds were sterilized with sodium hypochlorite $3 \%$ for $3 \mathrm{~min}$ and planted in $14 \mathrm{~cm}$ diameter Petri dishes. A $10 \mathrm{ml}$ of each solution was added to each petridish and transferred to a germinator at $25^{\circ} \mathrm{C}$. Germinated seed counting was done daily and final counting was on the $8^{\text {th }}$ day. At the end of the experiment, five seedlings from each plot randomly selected and radicle and plumule length and dry weight were recorded. Germination rate (GR) was calculated according to Ellis and Roberts (1981):

$$
G R-\frac{\sum n}{\Sigma(\Sigma n !}
$$

Where is the number of germinated seeds and Dn is the counting day.

Mean of daily germination (MDG) calculated by the formula below (Hunter et al., 1984): MDG=FGP/DGS

That FGP is the final germination percentage and DGS is daily germination speed.

Daily germination rate was calculated according to Maguir (1962): RDG=1/MDG

Primary and secondary seedling vigor was calculated from formula below (Abdul-Baki and Andersom, 1973):

SV1 = seedling dry weight (gr) germination percentage

SV2 = seedling length $(\mathrm{cm})$ germination percentage

Data analysis was performed using SAS 9.1 software after normal testing and comparison of means was performed using Duncan's multiple range test at $0.01 \%$ probability level.

\section{Results}

The effects of $\mathrm{HA}$ and $\mathrm{Cd}$ and their interaction were not significant for GP, GR, MGT and MDG, but the interaction was significant on radicle and plumule length, dry and fresh weight (Tab. 1).

Tab. 1. Analysis of variance table for the effect of cadmium and humic acid on the germination traits of pumpkin seeds

\begin{tabular}{ccccccccc}
\multicolumn{1}{c}{ SOV } & df & GP & GR & MTG & MDG & PL & RL \\
\hline $\begin{array}{c}\text { Cadmium } \\
(\mathrm{Cd})\end{array}$ & 2 & 21.69 & 0.001 & 0.063 & 0.34 & $21.69^{* *}$ & ${ }^{* *} 0.001$ \\
\hline $\begin{array}{c}\text { Humic } \\
\text { Acid }\end{array}$ & 4 & 113.78 & 0.0002 & 0.031 & 1.8 & ${ }^{* *} 113.78$ & ${ }^{* *} 0.0002$ \\
$(\mathrm{HA})$ & & & & & & & \\
\hline CdHA & 8 & 65.24 & 0.0017 & 0.161 & 5.3 & ${ }^{* *} 65.24$ & ${ }^{* *} 0.0017$ \\
\hline Error & 30 & 60.8 & 0.001 & 0.124 & 3.4 & 60.8 & 0.001 \\
\hline CV (\%) & & 8.9 & 10.8 & 11.56 & 30.5 & 8.9 & 10.8 \\
\hline
\end{tabular}

${ }^{* *}$ significant effect at $1 \%$ probability level. GP = germination percent, $\mathrm{GR}=$ germination rate, $\mathrm{MGT}=$ Mean of germination time, $\mathrm{MDG}=$ Mean of daily germination, $\mathrm{PL}=$ plumule length, $\mathrm{RL}$ = radicle length .

Tab. 1. Continue

\begin{tabular}{|c|c|c|c|c|c|c|c|c|c|}
\hline \multirow{2}{*}{ SOV } & \multirow{2}{*}{$\mathrm{df}$} & \multicolumn{8}{|c|}{ MS } \\
\hline & & RFW & PFW & CFW & RDW & PDW & CDW & $\mathrm{SV}_{2}$ & $\mathrm{SV}_{1}$ \\
\hline $\begin{array}{l}\text { Cadmium } \\
\text { (Cd) }\end{array}$ & 2 & $0.063^{* *}$ & $0.34^{* *}$ & 0.003 & $0.003^{* *}$ & $0.0021^{* *}$ & 0.045 & $20170.1^{* *}$ & $0.39^{* *}$ \\
\hline $\begin{array}{c}\text { Humic } \\
\text { Acid (HA) }\end{array}$ & 4 & $0.031^{* *}$ & $1.8^{* *}$ & 0.131 & $0.0005^{* *}$ & $0.0016^{* *}$ & 0.012 & $5076.6^{* *}$ & $0.24^{* *}$ \\
\hline $\mathrm{Cd}^{*} \mathrm{HA}$ & 8 & $0.161^{* *}$ & $5.3^{* *}$ & 0.133 & $0.0019^{* *}$ & $0.0023^{* *}$ & 0.027 & $21811.3^{* *}$ & $0.106^{* *}$ \\
\hline Error & 30 & 0.124 & 3.4 & 0.05 & 0.000044 & 0.000071 & 0.007 & 437.9 & 0.003 \\
\hline CV (\%) & & 11.56 & 30.5 & 12.53 & 10.27 & 15.45 & 12.01 & 13.48 & 16.29 \\
\hline
\end{tabular}

${ }^{* *}$ significant effect at $1 \%$ probability level. RFW = radicle fresh weight, PFW = plumule fresh weight, CFW = cotyledon fresh weight, RDW = radicle dry weight, $\mathrm{PDW}=$ plumule dry weight, $\mathrm{CDW}=$ cotyledon dry weight, SV1 = seedling weight index, SV2 = seedling length index

The longest radicle observed for $200 \mathrm{ppm} \mathrm{Cd}$ and 300 mg lit ${ }^{-1} \mathrm{HA}$ (86\% increase over control) and the shortest

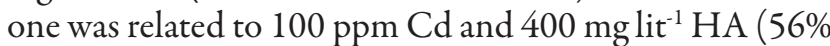
decrease in comparison with control) (Fig. 1). The longest plumule was observed in $200 \mathrm{ppm} \mathrm{Cd}$ and $400 \mathrm{mg} \mathrm{lit}^{-1} \mathrm{HA}$ (192\% increase over control) and the shortest one was re- 
lated to $400 \mathrm{mg} \mathrm{lit}^{-1} \mathrm{HA}$ without $\mathrm{Cd}$ ( $44 \%$ decrease over control)( Fig 2).

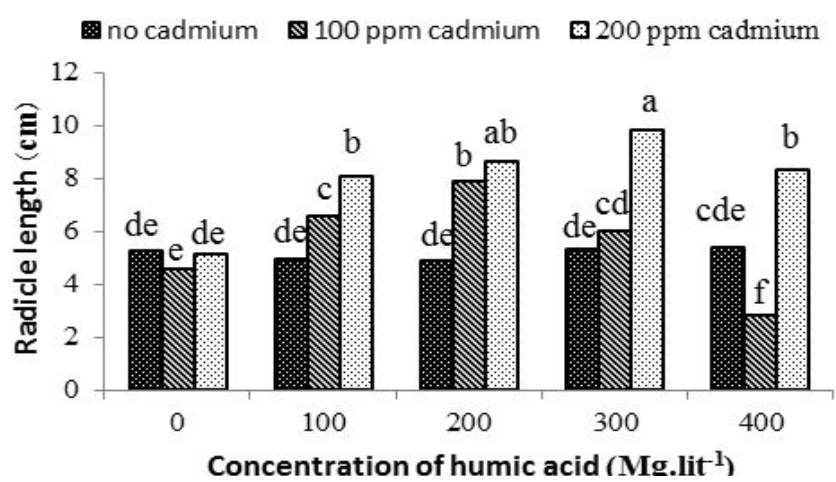

Fig. 1. Effect of Humic acid and cadmium concentration on pumpkin seedling radicle length

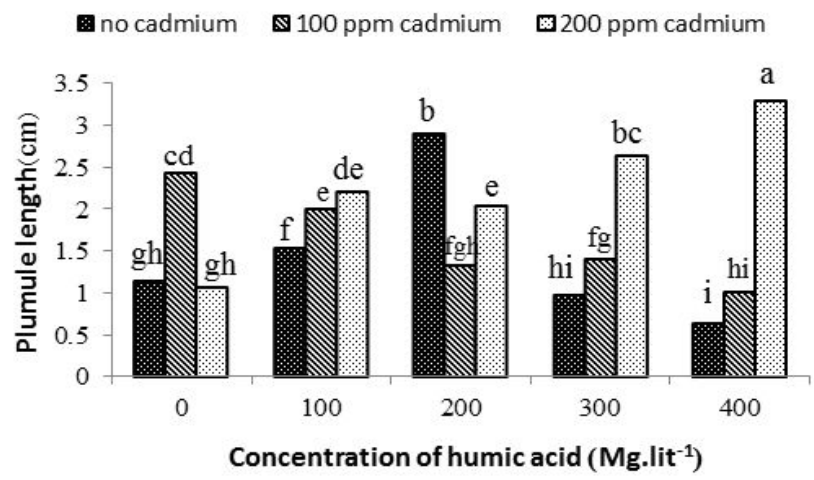

Fig. 2. Effect of humic acid and cadmium concentration on pumpkin seedling plumule length

Application of $200 \mathrm{ppm}$ Cd with $200 \mathrm{mg}$ lit-1 HA and $200 \mathrm{ppm} \mathrm{Cd}$ with $300 \mathrm{mg} \mathrm{lit}^{-1} \mathrm{HA}$, respectively produced the highest radicle and plumule fresh weight (respectively, $361 \%$ and $331 \%$ increase in comparison with control) (Fig. 3 and 4).

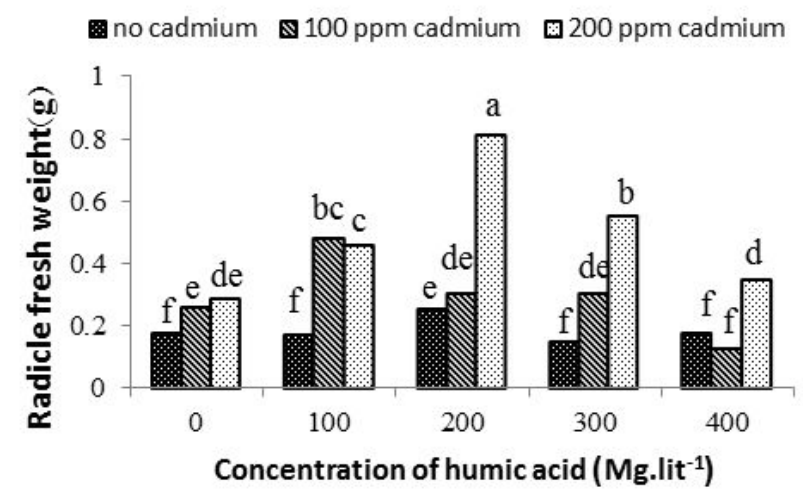

Fig. 3. Effect of humic acid and cadmium concentration on the radicle fresh weight of pumpkin seedling

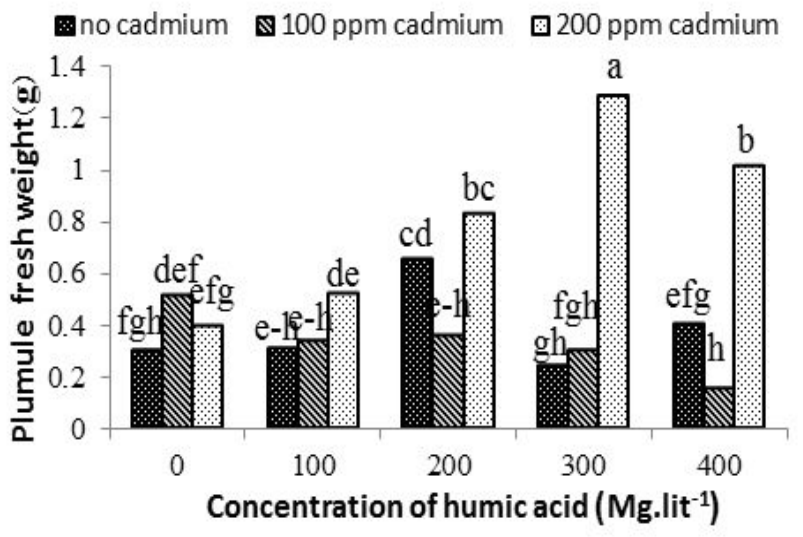

Fig. 4. Effect of humic acid and cadmium concentration on the plumule fresh weight of pumpkin seedling

The highest dry weight of radicle and plumule respectively, were observed in $200 \mathrm{ppm} \mathrm{Cd}$ with $400 \mathrm{mg} \mathrm{lit}^{-1} \mathrm{HA}$

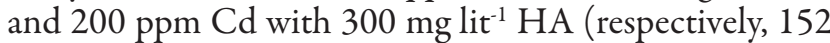
and $109 \%$ increase over control) (Fig. 5 and 6).

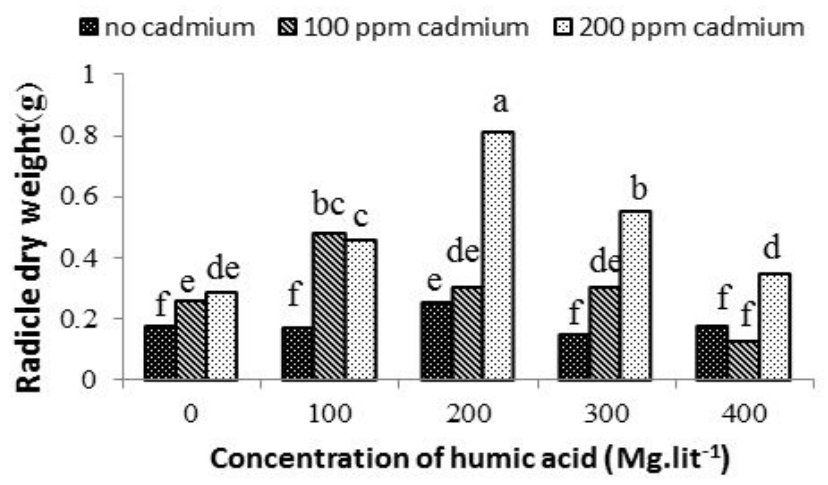

Fig. 5. Effect of humic acid and cadmium concentration on the radicle dry weight of pumpkin seedling

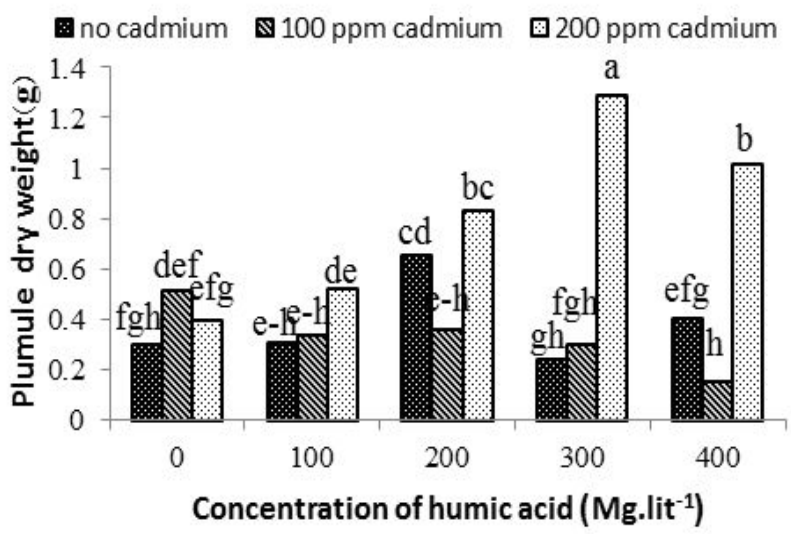

Fig. 6. Effect of humic acid and cadmium concentration on the plumule dry weight of pumpkin seedling 
The highest fresh and dry weight of cotyledon were observed in $100 \mathrm{ppm} \mathrm{Cd}$ with $200 \mathrm{mg} \mathrm{lit}{ }^{-1} \mathrm{HA}$ and 100 mg lit ${ }^{-1} \mathrm{HA}$ without $\mathrm{Cd}$, respectively (20 and $14 \%$ increase over control, respectively) (Fig. 7 and 8).

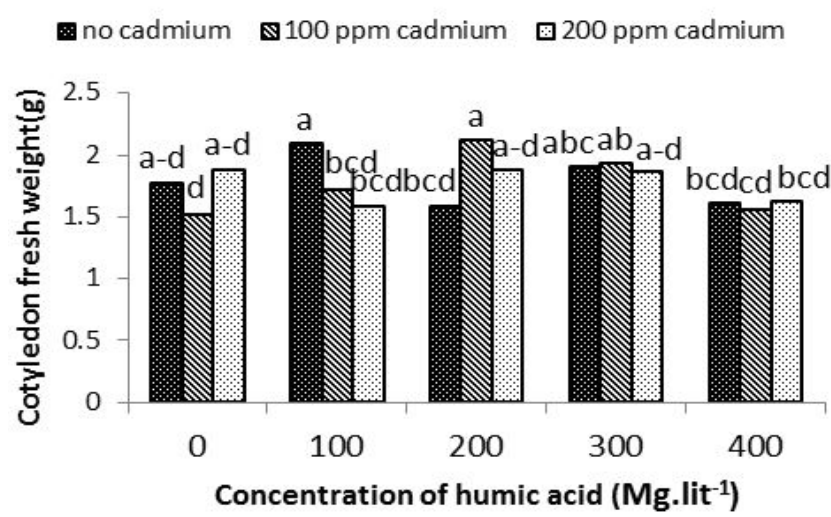

Fig. 7. Effect of humic acid and cadmium concentration on the cotyledon fresh weight of pumpkin seeds

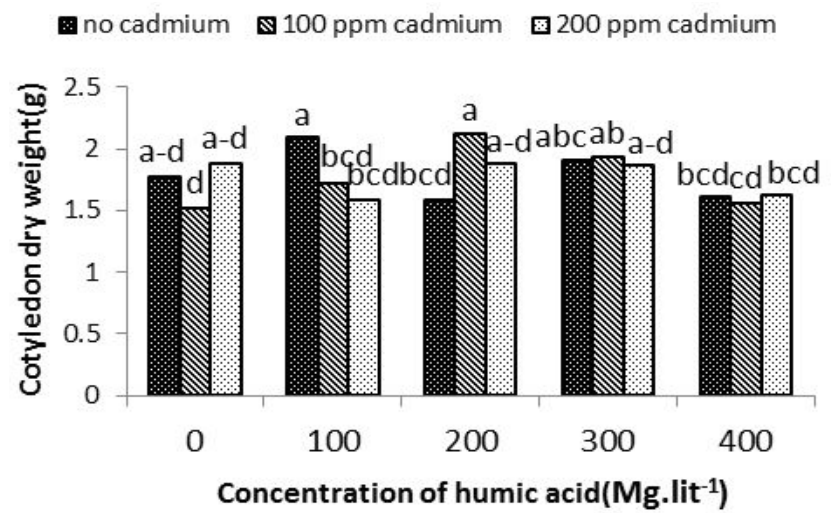

Fig. 8. Effect of humic acid and cadmium concentration on the cotyledon dry weight of pumpkin seeds

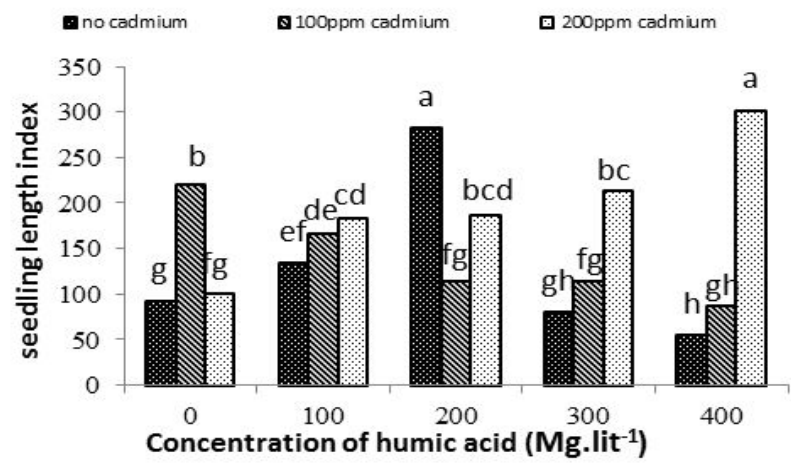

Fig. 9. Effect of humic acid and cadmium concentration on the length index of pumpkin seedlings

The highest seedling length index (301) was related to $400 \mathrm{mg} \mathrm{lit}^{-1} \mathrm{HA}$ and $200 \mathrm{ppm} \mathrm{Cd}$ (Fig. 9), and the highest seedling weight index (1) was also observed in the case of this treatment (Fig. 10).

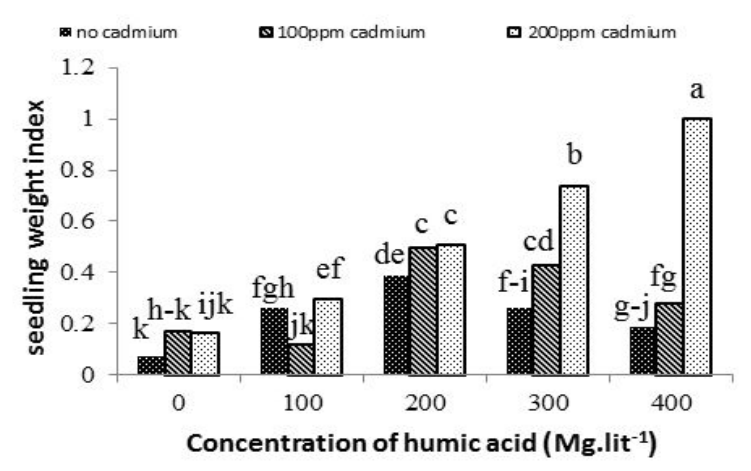

Fig. 10. Effect of humic acid and cadmium concentration on the weight index of pumpkin seedlings

\section{Discussion}

GP, MGT and GR were not affected by HA and Cd. It can be conculded that there is an antagonistic effect between HA and Cd. Amirjani (2012) reported that Cd can decrease GP of wheat seeds. GP and GR in wheat seeds (Saremi-Rad et al., 2011) and cowpea (AI-Rumaih et al., 2001) decreased in presence of Cd. Priming with HA and Cd increased GP and GR and decreased MGT in lettuce seeds (Mojahedi et al., 2011) and tomato (Piccolo et al., 1993). Jafari et al. (2011) reported an increase in radicle and plumule length of wheat seedlings in response to HA and Cd. Kouser and Azam (1985) found that application of $54 \mathrm{mg} \mathrm{lit}^{-1} \mathrm{HA}$ increases $50 \%$ in radicle length and 22\% in dry matter of wheat. HA in the concentration of $50 \mathrm{mg}$ lit $^{-1}$ increased cell elongation in pea root cells and higher concentrations had not significant effect (Vagan, 1974). Soltani et al. (2007) demonstrated that Cd decreases seedling dry and fresh weight and leaf area in rapeseed. HA increased root dry weight in bent grass and caused to increase in the activity of enzymes responsible for root respiration (Liu and Cooper, 2000). HA had an inhibitory effect on the activity of phosphatase in root cells and caused a decrease in root growth. Seed vigor also increased by applying HA and Cd (Vagan, 1974). These results are not in consistence with the results reported by Poschenreider et al. (1989). HA affected nitrate uptake and ATP-ase activity in the plasma membrane and caused cell elongation (Pinton et al., 1999).

\section{Conclusion}

Applying humic acid caused pumpkin seeds to be more tolerant to environmental stresses like heavy metals, especially Cd. In this experiment, a concentration of $300 \mathrm{mg}$ lit $^{-1}$ of HA had the betst results in detoxifying of $\mathrm{Cd}$ in high concentration (200 ppm). 


\section{References}

Abdul-Baki AA, Anderson JD (1973). Vigor determination in soybean by multiple criteria. Crop Science 13:630-633.

AI-Rumaih Muna M, Rushdy SS, Warsy AS (2001). Effect of Cadmium Chloride on seed germination and growth characteristics of Cowpea (Vigna unguiculata L.) plants in the presence and absence of Gibberellic Acid. Saudi J Biol Sci $8(1): 41-51$.

Amirjani MR (2012). Effects of Cadmium on Wheat growth and some physiological factors. Int J Forest Soil and Erosion $2(1): 50-58$.

Arancon Q, Clive A, Edwards S, Robert B (2006). Effects of Humic acids from vermicomposts on plant growth. European J of Soil Bio 42:S65-S69.

Barcelo J, Cabot C, Poschenrieder C (1986). Cadmium induced decrease of water stress resistance in Bush Bean plants (Phaseolus vulgaris L.). II. Effects of Cd on endogenous abscisic acid levels. Plant Physiol 125:27-34.

Cheng Y, Zhou QX (2002). Ecological toxicity of relative X3-B red dye and Cadmium acting on Wheat (Triticum aestivum). J Environ Sci. 14:136-140.

Egharevba Omoregie H (2010). Effect of Cadmium on seed viability of Vigna unguiculata. Ethnobotanical Leaflets 14: 413-19.

Ellis RH, Roberts EH (1981). The quantification of aging and survivial in orthodox seeds. Seed Science and Technology 9:377-409.

Gough LP, Shacklette HT, Case AA (1979). Element Concentrations Toxic to Plants, Animals and Man. U.S. Geological Survey, Washington, DC, p. 1466.

Hunter EA, Glasbey CA, Naylor R-E-L (1984). The analysis of data from germination tests. J Agri Sci Cambridge 102:207213.

Jafari HR, Khoramshahi D, Nabavi Kalat SM, Rabiei AR (2011). Effect of humic acid and biophosphorus on germination characteristics of two wheat cultivars. Paper presented at the Natinal congress on the new Acheivements in agriculture, Mashhad.

Karimi GH, Nojavan M (2008). Effects of cadmium chloride on growth parameters, proline content, the soluble protein and sugar content in Lentile (Lense miller) seedlings. Pajouhesh and Sazandegi 76:46-53.

Kauser A, Azam F (1985). Effect of Humic Acid on Wheat seeding growth. Envi and Exp Botany, 25:245 - 252.

Khatamiyan N, Radmehdi H, Nabavi Kalat, SM (2011). The effect of humic acid on germination charactristices of two cultivar $\mathrm{x}$ Triticosecale rimpaui Wittm. National congress on agricultural management. Jahrom.

Kiran Y, Shahin A (2006). The effects of Cadmium on seed germination, root development and miotic of root tip cells of Lentil (Lens culinaris Medik). World J Agric Sci 2(2):196200 .
Lashkari S. (1998). Pumpkin and prostate benign hypertrophy illnesses. Razi issue. 148:33.

Liu C, Cooper RJ (2000). Humic substances influence creeping bentgrass growth. Golf Course Management, 49-53.

Maguire JD (1962). Speed of germination, aid in selection and evaluation for seedling emergence and vigour. Crop Science 2:176-177.

Mohammadzade A, Chaichi M, Tavakoli M, Mohammadi M (2011). Germination response and seedling growth of annual alfalfa under heavy metal stress. Paper presented at the first national congress on the sustainable agriculture and production of organic products, Esfahan.

Mojahedi H, Amerian MR, Moradi H (2011). Effect of Humic Acid on germination traits and seedling growth of sunflower in different levels of Cadmium. Paper presented at the first national congress on the phytoremedation. Kerman.

Piccolo A, Celanoand G, Pietramellara G (1993). Effects of fractions of coal-derived Humic substanceon seed germination and growth of seedlings (Lactuca sativa and Lycopersiconesculentum). Biolferti Soil 16:11-15.

Pinton R, Cesco S, Iacolettig G, Astolfi S, and Varanini Z (1999). Modulation of NO3- uptake by water-extractable. Humic substances: involvement of root plasma membrane H+ATPase. Plant and soil 215:155-161.

Poschenreider CR, Gunse B, Barcelo I (1989). Influence of Cadmium on water relations, stomatal resistance and abscisic acid content in expanding bean leaves. PlantPhysiol 90:1365-1371.

Saremi-Rad B, Shokrpour M, Sofalian O, Avans A, Naderi H (2011). Effect of cadmium on germination of different Wheat genotype. Paper presented at the $2^{\text {nd }}$ national congress on the seed science and technology, Mashhad.

Smiri M (2010). Effect of Cadmium on germination, growth, redox and oxidative properties in Pisum sativum seeds. J of Environmental Chemistry and Ecotoxicology 3(3):52-59.

Soltani F, Ghorbanli M, Manouchehri Kalantari Kh (2007). Effect of Cadmium on photosynthetic pigments, sugars and malondealdehyde content in Brassica napus L. Iran Biology J, 19(2):136-145.

Tan K.H (2003). Humic Matter in Soil and Environment. Marcel Dekker, New york.

Turkman O, Demir S, Sensoy S, Dursun A (2005). Effect of Arbuscular Mycorrhizal Fungusand Humic Acid on the seedling development and nutrient content of Pepper grown under salin Soil conditions. J of Bio Sci 5(5):565-574.

Tyler VE, Brady LR, and Robbers JE (1988). Pharmacognosy $9^{\text {th }}$ Lea and Febiger Philadelpila, PA 464.

Vaughan D (1974). A possible mechanism for Humic Acid action on cell elongation in root segmentes of Pisum sativum aseptic condition. Soil Bio Biuchem 6:241-247. 